\title{
Glial scar-modulation as therapeutic tool in spinal cord injury in animal models ${ }^{1}$
}

\author{
Jéssica Rodrigues Orlandin', Carlos Eduardo Ambrósio"I, Valéria Maria Lara"
}

'Fellow Master degree, Postgraduate Program in Animal Bioscience, Veterinary Medicine Department, Faculty of Animal Science and Food Engineering, Universidade de São Paulo (FZEA/USP), Pirassununga-SP, Brazil. Intellectual, scientific, conception and design of the study; acquisition, analysis and interpretation of data; manuscript writing.

"Postdoctoral Researcher, Postgraduate Program in Animal Bioscience, Veterinary Medicine Department, FZEA/USP, Pirassununga-SP, Brazil. Conception and design of the study, critical revision, final approval.

II'Researcher, CNPq Grant Level 1A - CA VT, Veterinary Medicine Department, FZEA/USP, Pirassununga-SP, Brazil. Conception and design of the study, manuscript writing, critical revision, final approval.

\section{Abstract}

Purpose: Spinal Cord injury represents, in veterinary medicine, most of the neurological attendances and may result in permanent disability, death or euthanasia. Due to inflammation resulting from trauma, it originates the glial scar, which is a cell interaction complex system. Its function is to preserve the healthy circuits, however, it creates a physical and molecular barrier that prevents cell migration and restricts the neuroregeneration ability.

Methods: This review aims to present innovations in the scene of treatment of spinal cord injury, approaching cell therapy, administration of enzyme, anti-inflammatory, and other active principles capable of modulating the inflammatory response, resulting in glial scar reduction and subsequent functional improvement of animals.

Results: Some innovative therapies as cell therapy, administration of enzymes, immunosuppressant or other drugs cause the modulation of inflammatory response proved to be a promising tool for the reduction of gliosis

Conclusion: Those tools promise to reduce gliosis and promote locomotor recovery in animals with spinal cord injury.

Key words: Stem Cells. Inflammation. Neuroprotection. Models, Animal. 


\section{- Spinal cord injury in veterinary medicine}

Spinal Cord Injury (SCl) may have an endogenous or exogenous origin. Regardless of the cause, $\mathrm{SCl}$ are related to injury, compression, transaction, laceration, traction of the neural tissue, hemorrhage and hematoma, hypoxia, spinal cord laceration or the associated roots and others injuries resulting in varying degrees of neurological disorders ${ }^{1,2}$. Furthermore, physical interruption of nerve impulses and loss of blood flow and auto regulation, other biochemical, vascular and inflammatory events are involved in the neuronal destruction and necrosis ${ }^{3,4}$.

Endogenous capacity of self-repair and regenerate of the spinal cord is limited after injury ${ }^{5,6}$, due to the minor capacity of the replacement of damaged nerve cells ${ }^{7}$, as well as the production of growth inhibitory myelin associated axon and the formation of glial scar ${ }^{8}$.

The consequences of $\mathrm{SCl}$ in veterinary medicine, depending on the injured segment can lead to permanent disability or euthanasia.

\section{- Glial scar}

Glial scar consists predominantly of reactive astrocytes, macrophages, microglia and Chondroitin Sulfate Proteoglycans (CSPGs) that leads to a dense deposit of extracellular collagen matrix, acting as protective barrier scar, however, inhibits cell and axonal migration ${ }^{10}$.

Damage of the blood-brain barrier, leukocytes extravasations and accumulation of inflammatory cells in the center of the lesion are crucial events in the formation of the gliosis. Several molecules derived from blood or produced via inflammatory has been identified as a trigger for their induction, including interleukin-1, Transformation Growth Factor beta (TGF $\beta$ ) and fibrinogen ${ }^{11-15}$.
After the injury, fibroblasts migrate into the epicenter of the lesion, forming a fibrotic scar filled with extracellular fibronectin, collagen and laminin ${ }^{16}$. The proliferation of A-type pericytes contributes to the formation of the fibrosis, even in contused injuries, when meninges are intact and responsible for most of the components of the fibrotic scar. The glial scar appears in its mature form within two weeks after injury ${ }^{17,18}$.

Actived macrophages and microglia increase significantly the expression of matrix metalloproteinases (MMPs), which contributes to vascular permeability and accumulation of more inflammatory cells in the lesion, which reaches its peak around thirty days after injury ${ }^{19-21}$. Therefore, these activated cells, although important for the debridement of injured tissue, may also lead to secondary damage by inflammatory process ${ }^{22}$. Studies have shown that activated macrophages are responsible for the gradual and progressive death of axons after injury, trough the activity of MMPs and direct physical interaction with injured cells ${ }^{19,20}$.

Theglial response is mainly characterized by hypertrophy of astrocytes migrate out of the inflammatory epicenter, where they increase in size and present high gene expression of Glial Fibrillary Acidic Protein (GFAP), vimetin and nestin ${ }^{23,24}$. Hyperatrophic astrocytes are restructured into a network of tangled filamentous process, which acts protecting viable neural cells, however, resulting in a major physical barrier for axonal regeneration. Furthermore, studies suggest that glial scar prevents the inflammatory process to spread the healthy tissue $e^{25,26}$

\section{Inflammatory response modulation as a therapeutic approach}

Several authors associated gliosis modulation with the clinical response of spinal 
cordinjuryinanimais. In one study, GranulocyteMacrophage Colony-Stimulating Factor (GMCSF) was administered intraperitoneally, from 3 to 4 weeks after spinal cord injury in rats. There was a decrease in the expression of CSPGs and neurocan, intense expression of GFAP, preservation of axonal arrangement and structure in inflammatory myelin and improved gray matter and gliosis reduction ${ }^{27}$.

Yazdani et al. $^{28}$ compared the transplantation of cells from the olfactory epithelium and bone marrow-derived mesenchymal stem cells, neurally induced in rats with spinal cord injury. They concluded that the induced cells caused significantly motor improvement, reduction of the size of injury and axonal regeneration, making this strategy promising candidate for future therapies.

Another study has shown that Hepatocyte Growth Factor (HGF) has curative capacity by regulating TGF $\beta$, completely blocking the secretion of these factors on reactive astrocytes in vitro. The transplantation of cells capable of secrete HGF reduced neurocan expression and glycosaminoglycan deposition in the lesion and promoted axonal growth around the gliosis and functional improvement of the hindlimbs in rats ${ }^{29}$.

Ahmed et al. ${ }^{30}$ used decorin - a proteoglycan associated with collagen fibers to block the glial scar and cystic cavitation and induce fibrotic dissolution of gliosis in rats with chronic spinal cord injury. These mechanisms have been attributed to the induction capacity of MMPs and plasminogen activity, modulation of inflammation, removal of growth inhibitors and axonal regeneration promotion in the lesion.

Another study demonstrated the efficacy of transplantation dedifferentiated adipocytes in promoting locomotor improvement, remyelination, glial scar reduction and increased expression of neurotrophic factors in mice with spinal cord injury ${ }^{31}$.

Studies using curcimun - an active component of turmeric, which acts as an antiinflammatory - demonstrated the ability of the substance to reduces local inflammation, suppressing the formation of glial scar by inhiniting the process of reactive astrocytes cytokines and pro-inflammatory such as TNFTNF- $\alpha$, IL-1 $\beta$ e NK- $k b$, in addition to promote protection of neurons and axons after spinal cord injury in rodents ${ }^{32,33}$.

Rapamycin - an immunosuppressant used for the prophylaxis of organ transplant rejection - reduces infiltration of neutrophils and macrophages in the lesion, microglial activation, secretion of TNF $\beta$, the number of cells expressing GFAP, inhibited the proliferation of astrocytes and promoted neuronal survival and axiogenesis around the injury, being a good tool in the treatment of spinal cord injury in mice ${ }^{34}$.

Naïve Schwann cells and Schawann cells transduced to express GDNF which were seeded into guidance channels and implanted the spinal cord injury by Do-Thi et al. ${ }^{35}$, inhibit the formation of glial scar by promoting functional improvement in rats, when expressed LvshGFAP (lentiviral-mediated RNA-interference against GFAP). It was also observed growing axons and increased serotonergic innervation, suggesting that this type of therapy aids in the treatment of spinal cord injury.

Several studies using the enzyme chondroitinase $A B C^{36-39}$ in ratis demonstrated their potential in digesting CSPGs - inhibitory molecules predominant in glial scar - modifying the intra and extracellular architecture, reducing the formation of gliosis, regenerating axons injured by improving neural connections and promoting neuroprotection.

By intrathecal bone marrow cells transplantation, Zhu et al. ${ }^{40}$ demonstrated that gliosos is more associated with macrophages than microglia in mice. Depletion of these 
macrophages resulted in a reduction of fibroblasts and the formation of basal lamina, leading to a scar less fibrotic and more conducive to axonal growth.

The transplantation of neural progenitor cells in the spinal Cord injury showed the ability of these cells to inhibit astrocyte activation, reduce gliosis and promote improved locomotor in treated rats ${ }^{41-43}$.

In the following Table 1, a summary of the therapies addressed in this review can be observed:

Table 1 - Therapies to promote glial scar-modulation.

\begin{tabular}{|c|c|c|c|}
\hline Author & Therapy & Animal & $\begin{array}{c}\text { Route of } \\
\text { administration }\end{array}$ \\
\hline Zhu et al. ${ }^{40}$ & Bone Marrow cells & Mice & Intrathecal \\
\hline Yamada et al. ${ }^{31}$ & $\begin{array}{c}\text { Mature adipocyte-derived } \\
\text { dedifferentiated fat cells }\end{array}$ & Mice & \multirow{7}{*}{ Intramedullary } \\
\hline Yazdani et al. ${ }^{28}$ & $\begin{array}{c}\text { Olfactory epithelium and bone marrow- } \\
\text { derived mesenchymal stem cells } \\
\text { (neurally induced) }\end{array}$ & Rats & \\
\hline Jeong et al. ${ }^{29}$ & $\begin{array}{c}\text { HGF overexpressing mesenchymal stem } \\
\text { cells derived from human bone marrow } \\
\text { (HGF-MSCs) }\end{array}$ & Rats & \\
\hline Ahmed et al. ${ }^{30}$ & Decorin & Rats & \\
\hline Do-Thi et al. ${ }^{35}$ & Schwann cells & Rats & \\
\hline $\begin{array}{l}\text { Yick }^{36} \text {, Xia et al. }{ }^{37} \text {, Huang } \\
\text { et al. }{ }^{38} \text {, Ni et al. }{ }^{39}\end{array}$ & Chondroitinase $A B C$ & Rats & \\
\hline $\begin{array}{l}\text { Bonner et al. }{ }^{41} \text {, Jin et al. }{ }^{42} \text {, } \\
\text { Mitsui et al. }{ }^{43}{ }^{4}\end{array}$ & Neural progenitor cells & Rats & \\
\hline Huang et $a .^{27}$ & $\begin{array}{l}\text { Granulocyte-Macrophage Colony- } \\
\text { Stimulating Factor (GM-CSF) }\end{array}$ & Rats & \multirow{4}{*}{ Intraperitoneally } \\
\hline Yuan et $a .^{33}$ & Curcimun & Rats & \\
\hline Wang et $a l^{32}$ & Curcimun & Mice & \\
\hline Goldshmit et al. ${ }^{34}$ & Rapamycin & Mice & \\
\hline
\end{tabular}

\section{- Conclusion}

Spinal Cord injuries represent the majority of neurological manifestations in veterinary medicine. Gliosis is characterizes by replacement of functional tissue by fibrous after injury, in order to promote protection of healthy cells. This process, however, implies a physical and molecular barrier that inhibits cell and axon migration and thus prevents the functional improvement.
As a way of reversing or deflecting this event, studies have shown that modulation of the inflammatory response at the wound site results in a reduction in lesions size, neuronal survival, protection growth, remyelination and increased innervations, leading to a reduction, inhibition or reversal of glial scar and promotes improved locomotor to treated animals.

We conclude that either by cell therapy, administration of enzymes, immunosuppressant or other drugs, the 
modulation of inflammatory response proved to be a promising tool for the reduction of gliosis, aiding locomotor recovery in animals with spinal cord injury.

\section{References}

1. McDonald JW, Sadowsky C. Spinal-cord injury. Lancet. 2002;359:417-25. doi: 10.1016/ S0140-6736(02)07603-1.

2. Henke D, Vandevelde M. Dohher M, Stöckli $\mathrm{M}$, Forterre F. Correlations between severity of clinical signs and histopathological changes in 6 dogs with spinal cord injury associated with acute thoracolumbar intervertebral disc disease. Vet Jl. 2013;198:70-5. doi: 10.1016/j. tvjl.2013.04.003.

3. Tymianski $\mathrm{M}$, Tator $\mathrm{CH}$. Normal and abnormal calcium homeostasis in neurons: a basis for the pathophysiology of traumatic and ischemic central nervous system injury. Neurosurgery. 1996;38(6):1176-95. PMID: 8727150.

4. Arias MVB, Nishioka CM, Garcia CO, Reia AZ, Baraúna Júnior D, Marcasso RA. Avaliação dos resultados clínicos após cirurgia descompressiva em cães com doença de disco intervertebral. Arq Bras Med Veterinária e Zootec. Esc Vet UFMG. 2007;59(6):1445-50. doi: 10.1590/S0102-09352007000600015.

5. Frisén J, Johansson $C B$, Török $C$, Risling $M$, Lendahl U. Rapid, widespread, and longlasting induction of nestin contributes to the generation of glial scar tissue after CNS injury. J Cell Biol. 1995;131(2):454-64. PMID: 7593171.

6. Zai L, Wrathall JR. Cell proliferation and replacement following contusive spinal cord injury. Glia. 2005;50(3):247-57. PMID: 15739189.

7. Johansson CB, Momma S, Clarke DL, Risling M, Lendahl $U$, Frisén J. Identification of a neural stem cell in the adult mammalian central nervous system. Cell. 1999;96:25-34. doi: 10.1016/S0092-8674(00)80956-3.

8. Olson L. Medicine: clearing a path for nerve growth. Nature. 2002;416(6881):589-90. PMID: 11948332.

9. Rolls A, Shechter R, London A, Segev $Y$, Jacob-Hirsch J, Amariglio N, Rechavi G, Schwartz M. Two faces of chondroitin sulfate proteoglycan in spinal cord repair: a role in microglia/macrophage activation. PLoS Med. 2008;5(8):1262-77. doi: 10.1371/journal. pmed.0050171.

10. Silver J, Miller JH. Regeneration beyond the glial scar. Nat Rev Neurosci. 2004;5(2):146-56. PMID: 14735117.

11. Giulian D, Woodward J, Young DG, Krebs JF, Lachman LB. Interleukin-1 injected into mammalian brain stimulates astrogliosis and neovascularization. J Neurosci. 1988;8(7):2485-90. PMID: 2470873.

12. Asher RA, Morgenstern DA, Fidler PS, Adcock KH, Oohira A, Braistead JE, Levine $\mathrm{JM}$, Margolis RU, Rogers JH, Fawcett JW. Neurocan is upregulated in injured brain and in cytokine-treated astrocytes. J Neurosci. 2000;20(7):2427-38. PMID: 10729323.

13. Moon LDF, Fawcett JW. Reduction in CNS scar formation without concomitant increase in axon regeneration following treatment of adult rat brain with a combination of antibodies to TGFbeta1 and beta2. Eur J Neurosci. 2001;14(10):1667-77. doi: 10.1046/j.0953816x.2001.01795.x.

14. Schachtrup C, Ryu JK, Helmrick MJ, Vagena E, Galanakis DK, Degen JL, Margolis RU, Akassoglou K. Fibrinogen triggers astrocyte scar formation by promoting the availability of active TGF-beta after vascular damage. J Neurosci. 2010;30(17):5843-54. doi: 10.1523/ JNEUROSCI.0137-10.2010.

15. Ertürk A, Mauch CP, Hellal F, Förstner F, Keck $T$, Becker $K$,Jährling $N$, Richter $M$, Hübener M, Kramer E, Kirchhoff F, Dodt HU, Bradke F. Three-dimensional imaging of the unsectioned adult spinal cord to assess axon regeneration and glial responses after injury. Nat Med. 2012;18:166-71. PMID: 22198277.

16. Shearer MC, Fawcett JW. The astrocyte/ meningeal cell interface--a barrier to successful nerve regeneration? Cell Tissue Res. 2001;305(2):267-73. PMID: 11545264.

17. Göritz C, Dias DO, Tomilin N, Barbacid M, ShupliakovO, Frisén J. A pericyte origin of spinal cord scar tissue. Science. 2011;333(6039):23842. PMID: 21737741.

18. Soderblom C, Luo X, Blumenthal E, Bray E, Lyapichev K, Ramos J, Krishnan V, Lai-Hsu C, Park 
KK, Tsoulfas P, Lee JK. Perivascular fibroblasts form the fibrotic scar after contusive spinal cord injury. J Neurosci. 2013;33(34):13882-7. doi: 10.1523/JNEUROSCI.2524-13.2013.

19. Horn KP, Busch SA, Hawthorne AL, Van Rooijen $\mathrm{N}$, Silver J. Another barrier to regeneration in the CNS: activated macrophages induce extensive retraction of dystrophic axons through direct physical interactions. J Neurosci. 2008;28(38):9330-41. doi: 10.1523/ JNEUROSCI.2488-08.2008.

20. Kigerl KA, Gensel JC, Ankeny DP, Alexander JK, Donnelly DJ, Popovich PG. Identification of two distinct macrophage subsets with divergent effects causing either neurotoxicity or regeneration in the injured mouse spinal cord. J Neurosci. 2009;29(43):13435-44. doi: 10.1523/JNEUROSCI.3257-09.2009.

21. Noble LJ, Donovan F, Igarashi T, Goussev S, Werb Z. Matrix metalloproteinases limit functional recovery after spinal cord injury by modulation of early vascular events. J Neurosci. 2002;22(17):7526-35. PMID: 12196576.

22. Fitch MT, Doller C, Combs CK, Landreth GE, Silver J. Cellular and molecular mechanisms of glial scarring and progressive cavitation: in vivo and in vitro analysis of inflammation-induced secondary injury after CNS trauma. J Neurosci. 1999;19:8182-98. PMID: 10493720.

23. Faulkner JR, Herrmann JE, Woo MJ, Tansey KE, Doan NB, Sofroniew MV. Reactive astrocytes protect tissue and preserve function after spinal cord injury. J Neurosci. 2004;24(9):214355. PMID: 14999065.

24. Barrett CP, Guth L, Donati EJ, Krikorian JG. Astroglial reaction in the gray matter lumbar segments after midthoracic transection of the adult rat spinal cord. Exp Neurol. 1981;73(2):365-77. PMID: 6167460.

25. Okada S, Nakamura M, Katoh H, Miyao T, Shimazaki T, Ishii K, Yamane J, Yoshimura A, Iwamoto Y, Toyama Y, Okano H. Conditional ablation of Stat3 or Socs3 discloses a dual role for reactive astrocytes after spinal cord injury. Nat Med. 2006;12(7):829-34. PMID: 16783372.

26. Wanner IB, Anderson MA, Song B, Levine J, Fernandez A, Gray-Thompson Z, Ao Y, Sofroniew MV. Glial scar borders are formed by newly proliferated, elongated astrocytes that interact to corral inflammatory and fibrotic cells via STAT3-dependent mechanisms after spinal cord injury. J Neurosci. 2013;33(31):12870-86. doi: 10.1523/JNEUROSCI.2121-13.2013.

27. Huang X, Kim J-M, Kong TH, Park SR, Ha Y, Kim $\mathrm{MH}$, Park H, Yoon SH, Park HC, Park JO, Min BH, Choi BH. GM-CSF inhibits glial scar formation and shows long-term protective effect after spinal cord injury. J Neurol Sci. 2009;277:8797. doi: 10.1016/j.jns.2008.10.022.

28. Yazdani SO, Pedram M, Hafizi M, Kabiri $M$, Soleimani $M$, Dehghan $M-M$, Jahanzad I, Gheisari Y, Hashemi SM. A comparison between neurally induced bone marrow derived mesenchymal stem cells and olfactory ensheathing glial cells to repair spinal cord injuries in rat. Tissue Cell. 2012;44(4):205-13. doi: 10.1016/j.tice.2012.03.003.

29. Jeong SR, Kwon MJ, Lee HG, Joe EH, Lee JH, Kim SS, Shu-Kim H, Kim BG. Hepatocyte growth factor reduces astrocytic scar formation and promotes axonal growth beyond glial scars after spinal cord injury. Exp Neurol. 2012;233:312-22. doi: 10.1016/j. expneurol.2011.10.021.

30. Ahmed Z, Bansal D, Tizzard K, Surey S, Esmaeili M, Gonzalez AM, Berry M, Logan A. Decorin blocks scarring and cystic cavitation in acute and induces scar dissolution in chronic spinal cord wounds. Neurobiol Dis. 2014;64:163-76. doi: 10.1016/j.nbd.2013.12.008.

31. Yamada H, Ito D, Oki Y, Kitagawa M, Matsumoto T, Watari T, Kano K. Transplantation of mature adipocyte-derived dedifferentiated fat cells promotes locomotor functional recovery by remyelination and glial scar reduction after spinal cord injury in mice. Biochem Biophys Res Commun. 2014;454 (2):341-6. doi: 10.1016/j. bbrc.2014.10.082.

32. Wang Y-F, Zu J-N, Li J, Chen C, Xi C-Y, Yan J-L. Curcumin promotes the spinal cord repair via inhibition of glial scar formation and inflammation. Neurosci Lett. 2014;560:51-6. doi: 10.1016/j.neulet.2013.11.050.

33. Yuan J, Zou M, Xiang X, Zhu H, Chu W, Liu W, Chen F, LinJ.Curcumin improvesneural function after spinal cord injury by the joint inhibition of the intracellular and extracellular components 
of glial scar. J Surg Res. 2015;195:235-45. doi: 10.1016/j.jss.2014.12.055.

34. GoldshmitY, KannerS, Zacs M, Frisca F, Pinto AR, Currie PD, Kramarski RP. Rapamycin increases neuronal survival, reduces inflammation and astrocyte proliferation after spinal cord injury. Mol Cell Neurosci. 2015;68:82-91. doi: 10.1016/j.mcn.2015.04.006.

35. Do-Thi A, Perrin FE, Desclaux M, Saillour $P$, Amar L, Privat A, Mallet J. Combination of grafted Schwann cells and lentiviral-mediated prevention of glial scar formation improve recovery of spinal cord injured rats. J Chem Neuroanat. 2016;76:48-60. doi: 10.1016/j. jchemneu.2015.12.014.

36. Yick L. Axonal regeneration of Clarke's neurons beyond the spinal cord injury scar after treatment with chondroitinase $A B C$. Exp Neurol. 2003;182:160-8. doi: 10.1016/S00144886(02)00052-3.

37. Xia Y, Zhao T, Li J, Li L, Hu R, Hu S, Feng $\mathrm{H}$, Ln J. Antisense vimentin cDNA combined with chondroitinase $A B C$ reduces glial scar and cystic cavity formation following spinal cord injury in rats. Biochem Biophys Res Commun. 2008;377(2):562-6. doi: 10.1016/j. bbrc.2008.10.024.

38. Huang W-C, Kuo W-C, Hsu S-H, Cheng C-H, Liu J-C, Cheng H. Gait analysis of spinal cord injured rats after delivery of chondroitinase $\mathrm{ABC}$ and adult olfactory mucosa progenitor cell transplantation. Neurosci Lett. 2010;472(2):7984. doi: 10.1016/j.neulet.2010.01.012.

39. Ni S, Xia T, Li X, Zhu X, Qi H, Huang S, Wang J. Sustained delivery of chondroitinase $A B C$ by poly(propylene carbonate)-chitosan micron fibers promotes axon regeneration and functional recovery after spinal cord hemisection. Brain Res. 2015;1624:469-78. doi: 10.1016/j.brainres.2015.08.018

40. Zhu Y, Soderblom C, Krishnan V, Ashbaugh J, Bethea JR, Lee JK. Hematogenous macrophage depletion reduces the fibrotic scar and increases axonal growth after spinal cord injury. Neurobiol Dis. 2015;74:114-25. doi: 10.1016/j.nbd.2014.10.024.

41. Bonner JF, Blesch A, Neuhuber B, Fischer I. Promoting directional axon growth from neural progenitors grafted into the injured spinal cord. J Neurosci Res. 2010;88(6):118292. doi: 10.1002/jnr.22288.

42. Jin Y, Bouyer J, Shumsky JS, Haas C, Fischer I. Transplantation of neural progenitor cells in chronic spinal cord injury. Neurosci Oxford. 2016;320:69-82. doi: 10.1016/j. neuroscience.2016.01.066.

43. Mitsui T, Kakizaki H, Tanaka H, Shibata T, Matsuoka I, Koyanagi T. Immortalized neural stem cells transplanted into the injured spinal cord promote recovery of voiding function in the rat. J Urol. 2003;170:1421-5. doi: 10.1097/01.ju.0000075501.05758.33.

\section{Correspondence:}

Carlos Eduardo Ambrósio

Faculdade de Zootecnia e Engenharia de Alimentos (FZEA-USP)

Departamento de Medicina Veterinária

Rua Duque de Caxias Norte, 225 - Campus

Fernando Costa

13635-900 Pirassununga - SP Brasil

ceambrosio@usp.br

Conflict of interest: none

Financial source: none
Received: Oct 14, 2016

Review: Dec 19, 2016

Accepted: Jan 20, 2017 